\title{
Restoration of damaged geofoundations in transport using highly-effective repair mortar
}

\author{
Valentina Soloviova ${ }^{1}$, Dmitriy Soloviov ${ }^{1}$, Irina Stepanova ${ }^{1,{ }^{*}}$, and Anna Kasatkina ${ }^{1}$ \\ ${ }^{1}$ Emperor Alexander I St.Petersburg State Transport University. 190031, Saint Petersburg, \\ Moskovsky pr., 9, Russia
}

\begin{abstract}
The area of the research is geoconstruction and geostructures in transport. The present study provides modified repair mortars characterized by high penetrating performance, which is important in geoconstruction and transport. Penetrating repair mortars increase compression strength by 1-3 classes, water-resistance by 4-10 atm of the operated concrete geofoundation. Modified repair mortars are of increased crack resistance, they are carbon dioxide and magnesia corrosion resistant material and also they are characterized by high adhesion strength to a concrete geofoundation, which creates a monolithic character of both a restored foundation and a repair geocomposition.
\end{abstract}

\section{Introduction}

One of the most important issues of our time is restoring concrete geostructures of $20^{\text {th }}$ century weakened and damaged under external stresses and environmental impact. Furthermore, one of the important objectives is improving physical-mechanical properties of operated concrete geostructures since the quality requirements are always increasing [1-7].

To address the problem it is necessary to create a highly effective repair mortar, capable of penetrating deep into a concrete geofoundation improving its properties. Later on this mixture, having improved quality parameters and increased adhesional strength, could give an effective protection of the restored or the reinforced foundation. The efficiency of the repair mortar can be achieved by modifying it with additives of a certain nature which are capable of penetrating into foundation and activating hydration processes as well. To obtain a repair mortar of complex performance, it is necessary to create highly-effective chemical additives of a new type. The present research deals with the solution of this problem.

\section{Methods and materials}

The development of penetrating mortars is based on the ideas of possible mobility of fine particles. The penetration of fine particles from the mortar into the foundation are based on the ideas of transportation mechanisms of ions and nanoparticles (1-100 nm), characterized by high mobility which results in their penetrating into the geofoundation pores involving the particles of the appropriate size from the mortar, e.g. newly-formed hydrated compounds.

\footnotetext{
*Corresponding author: 9046185117@mail.ru
} 
It is known that cations of large size are also characterized by high mobility as a result of hydrogen bonds splitting in water structure and negative hydration, i.e. the longer cation's radius is, the less salvation shell is and the higher its mobility is.

To enhance the penetrating performance of the repair mortar it is advisable to modify the mortar using chemical additives the main components of which should be salt solutions based on metals of I group of the main subgroup or colloidal solutions, containing nanodispersions of different nature.

In the cement-base repair mortar hydration processes take place and complex hydrated compounds are formed being at first of colloidal or nanosize. Consequently, the newlyformed hydrated compounds, which at the moment of formation are of the size $\approx(1-100) \mathrm{nm}$, also will be penetrating into the concrete geofoundation increasing the number of hydrosilicates in the restored geostructure. Also, the unreacted cement in the pores of the concrete foundation takes part in hydration process under the action of the effective chemical additives, penetrating from the modified mortar into the foundation.

The penetration of hydrated compounds as well as the formation of new hydrated compounds in the foundation will provide restoration or improvement of physical-mechanical properties of the foundation [8-12].

Monolithic character of the repair mortar and the repaired concrete foundation is provided by the quality of the contact zone between the modified mortar and the concrete foundation.

The durability of the contact zone in the interaction of the modified mortar with the foundation surface is formed as a result of the donor-acceptor interaction between the components of the mortar with the components of the concrete foundation.

Figure 1 shows the interaction of the mortar with the concrete foundation.

a)

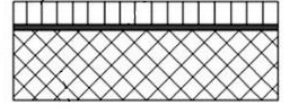

b)

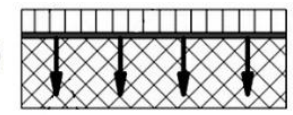

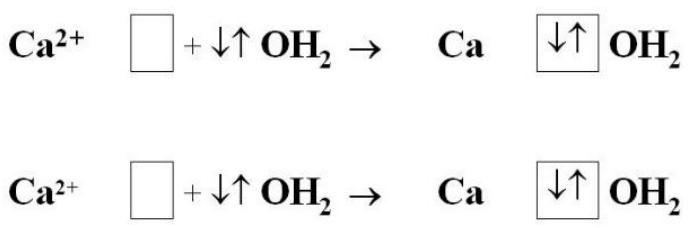

Fig. 1. Interaction of mortar with foundation, where: a) the mortar, giving a protective action; b) the mortar, giving a penetrating action.

The reactions shown in Figure 1 confirm that the contact is formed as a result of donoracceptor interaction, where calcium ions (acceptors) - oxygen electron pairs (donors) [1317]. Therefore, the more hydrated compounds are formed in the mortar and the concrete foundation, the more durable the contact zone will be and the higher its adhesional strength is. The increase of strength and other physical-mechanical characteristics of the concrete foundation can be achieved by increasing the number of hydrated phases formed particularly in the foundation. The efficiency of the mortar is supposed to be enhanced by using a chemical additive one of the components of which is, for example, silica sol. The concentration of silica sol hydrogen ions is $\mathrm{pH}=3-4$. The characteristic of silica sol is that it interacts with $\mathrm{Ca}(\mathrm{OH}) 2$, which results in formation of additional amount of calcium hydrosilicates affecting the shift of chemical balance towards the formation of new silicates which are supposed to be formed in the repair mortar and in the restored foundation. As an activating component in the mortar composition it is efficient to input electrolytes based on metal cations of I group of the main subgroup which are supposed to increase hydration of the repair mortar and the 
restored foundation. Repair mortars, modified by the researched chemical additive, containing the components of the specified nature are likely to restore and improve physical-mechanical characteristics of the concrete foundation and in the future protect it from the negative impact of the environment. The scientific and experimental-industrial research was done to confirm the hypothesis. The aim of the research was to find the most efficient electrolyte and the colloidal solution based on dispersions of a certain nature for creating an efficient mortar. The quality of the modified mortar was measured by compression strength, bending tensile strength and metal crack resistance. The evaluation of the modified mortar performance was conducted by the change of compression strength, water resistance, frost resistance, and corrosion resistance of the concrete foundation. For this purpose we used concretes B20 and B22,5 as being the most exposed to destroying during operation.

\section{Research results and discussions}

We did the research on aqueous solutions of electrolytes based on the cations of the following metals: $\mathrm{Li}(\mathrm{I}), \mathrm{Na}(\mathrm{I}), \mathrm{K}(\mathrm{I}), \mathrm{Rb}(\mathrm{I})$ and $\mathrm{Cs}(\mathrm{I})$ with anions of different nature. The experiments have proved that penetration capability of electrolyte depends on its nature and aqueous solution concentration. It has been determined that cations, using electrolyte solution of $6 \%$ concentration, are characterized by maximum mobility, whatever the anion, which was used in further studies. It has been established experimentally that the rational number of the studied electrolytes of $6 \%$ concentration is $3.0 \%$ of cement mass.

The best results of the change of compression strength and bending tensile strength of the repair material were obtained using electrolytes based on cations of potassium $\mathrm{K}(\mathrm{I})$ and caesium Cs(I), whereas the increase of bending tensile strength $25-30 \%$ is faster than that of compression strength.

It has been established by calculation and experimental methods that the repair material modified by the mentioned electrolytes is characterized by a high crack resistance which is measured by crack resistance coefficient found due to formula: $C c r=\frac{R_{t n s}}{R_{c m p r}}$

The best results were obtained using potassium nitrates $\mathrm{KNO} 3$ or caesium nitrates $\mathrm{CsNO} 3$ because their use increases crack resistance coefficient of the repair material $\mathrm{Ccr} .=0,31-$ 0,34 , which characterizes it as material of high crack resistance. Adding silica sol solution $\mathrm{SiO} 2 \mathrm{nH} 2 \mathrm{O}$ as an additive into the repair mortar makes it possible to increase the durability of the repair material to a greater extent than using electrolytes. What is more, in this case bending tensile strength mostly increases. The effectiveness of the repair mortar is in its capability to restore a concrete geofoundation which is achieved not only by reactional activity of the components but also by its capability to penetrate into a geofoundation as deeper as possible. To provide the maximum moving of the mortar components deep into the concrete foundation it is advisable to increase additionally the mobility of all the components of the repair mortar, e.g. using modern highly-active surfactants, preferably on polycarboxylate basis, which are well-compatible both with silica sol and with the mentioned electrolytes.

Co-occurrence of hyperplasticizer on polycarboxylate basis and modificators like KNO3 or sol $\mathrm{SiO} 2 \mathrm{nH} 2 \mathrm{O}$, is favorable and provides a higher effect in pushing the particles into the concrete foundation forming the most homogeneous structure by the height of a concrete structure. When treating a concrete geofoundation by the mortar, pore spaces of the foundation are filled with fine particles of the mortar, resulting in increase of the pore structure density. According to the microscopic examinations, carried out with the help of VideoTest automatic image analyser, it has been established that the average size of the foundation pores $(\varnothing)$ and the percentage of the pore square, S, on the sample surface decrease in the following order: 


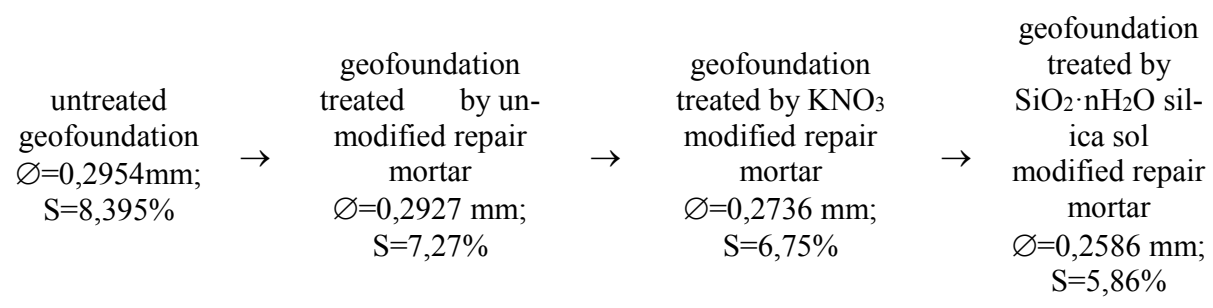

The compaction of the geofoundation structure results in improvement of compression strength indicators. For concretes B20 and B22,5 the durability increases by 3 classes from B20 class to B30 class and from B22,5 class to B35 class. Also the indicators of longevity are increased, such as water resistance and frost resistance.

It has been established by experimental means that frost resistance is increased by 100 250 cycles depending on the reference value of frost resistance. Water resistance is increased by 3-4 grades. The highest increase is observed at $6-8$ atm reference value of water resistance of the geofoundation.

As a result of the geofoundation compaction as well as chemical reactions the corrosion resistance of the foundation is increased in relation to $5 \% \mathrm{Na} 2 \mathrm{CO} 3$ solution and $5 \% \mathrm{MgCl}$ solution. The corrosion resistance of the concrete foundation is increased by more than $15 \%$ if the foundation is treated by the repair mortar modified by $\mathrm{KNO} 3$ and $\mathrm{SiO} 2 \mathrm{nH} 2 \mathrm{O}$ silica sol additives. And Cchm rst of the treated concrete foundation reaches the values $\geq 0,85$.

To evaluate the integrity of the composition "concrete geofoundation-repair material" the value of adhesion strength is used. It has been established experimentally that adhesion strength to a concrete geofoundation surface changes within 2,8-3,2 MPa depending on the foundation durability. Also it has been established that in design age adhesion strength is approximately $27 \%$ higher if using the mortar modified by silica sol than if using the modifier represented by $\mathrm{KNO}_{3}$ electrolyte. The obtained data are in accordance with the works [1824] explaining the influence of such kind of substances on the hardening process.

\section{Conclusions}

It has been established that the repair mortar, modified by the additives represented by $6 \%$ $\mathrm{KNO}_{3}$ solution, silica sol, combined with surfactants on polycarboxylate basis, - has a higher penetrating performance, which has a positive influence on:

- Compression strength increase

- Adhesion strength increase

- Water resistance increase

- Frost resistance increase

- Corrosion resistance increase

The modified repair mortar provides restoration of the mentioned quality parameters of a weakened or a damaged concrete geofoundation up to design values or higher.

\section{References}

1. V.Y. Soloviova, P.A. Kozin, I.V. Stepanova, T.V. Smirnova, Journal Science and Technology 2(70), ISSN 1684-2026 (2014)

2. V.Y. Soloviova, I.V. Stepanova, T.V. Smirnova, Materials of 1st International Scientific-Practical Conference (Publishing House «Sputnik+», Moscow, 2014)

3. V.Y. Soloviova, A.S. Kasatkina, D.V. Soloviov, Materials of 1 st International Scientific-Practical Conference (Publishing House «Sputnik+», Moscow, 2014) 
4. V.Y. Soloviova, L.L. Maslennikiva, N.V. Ershikov, T.I. Boykova, A.V. Kasatkina, A.A. Kabanov, S.P. Kasatkin, Transport Construction 10, 13-15 (2016)

5. L. Svatovskaya, V. Soloviova, A. Sychova, L. Maslennikova, M. Sychov, Indian Journal of Science and Technology 9(42), 104304 (2016)

6. L. Svatovskaya, V. Soloviova, A. Sychova, L. Maslennikova, M. Sychov, Indian Journal of Science and Technology 9(42), 104304 (2016)

7. V.Y. Soloviova, T.I. Boykova, S.P. Kasatkin, et.al. Materials of $2^{\text {nd }}$ International Scientific-Practical Conference (Publishing House «Sputnik+», Moscow, 2016)

8. V.Y. Soloviova, T.I. Boykova, Collection of Scientific works of Participants of Scientific-Practical Seminar HI MTO named after A. Khrulev, 43-44 (2016)

9. V.Y. Soloviova, T.I. Boykova, S.P. et.al. Materials of 3rd International ScientificPractical Conference (Publishing house «Sputnik+», Moscow, 2016)

10. V. Soloviova, V. Kondratov, I. Stepanova, Pavements Procedia Engineering 189, 823828 (2017) https://doi.org/10.1016/j.proeng.2017.05.128

11. V. Soloviova, T. Boikova, D. Solovyov, Pavements Procedia Engineering 189, 800-804 (2017) https://doi.org/10.1016/j.proeng.2017.05.124

12. V. Soloviova, T. Boikova, D. Solovyov, Pavements Procedia Engineering 189, 650-653 (2017) https://doi.org/10.1016/j.proeng.2017.05.103

13. V.Y. Soloviova, L.L. Maslennikiva, M. Abu-Khasan, I.V. Stepanova, T.V. Smirnova, T.I. Boykova, V.V. Makarov, S.P. Kasatkin, Sciences and Technologies 2(104), 156162 (2017)

14. V.Y. Soloviova, M. Abu-Khasan, N.V. Ershikov, D.V. Soloviov, G.A. Miraev, Transport Construction 12 (2017)

15. L.B. Svatovskaya, V.Y. Soloviova, P.G. Komokhov, I.V. Stepanova, A.M. Sycheva, Patent for Invention RUS 2256629 26.03.2004

16. L.B. Svatovskaya, V.Y. Soloviova, I.V. Stepanova, A.E. Kniazev, Sciences and Technologies 3(65), 145-148 (2013)

17. V.Y. Soloviova, P.A. Kozin, I.V. Stepanova, T.V. Smirnova, Sciences and Technologies 2(70), 296-298 (2014)

18. L.B. Svatovskaya, A.A. Kabanov, M.M. Sychov, IOP Conference Series: Earth and Environmental Science 90, 012010, $1755-1315$ (2017) DOI: 10.1088/17551315/90/1/012010,

19. L.B. Svatovskaya, A.A. Kabanov, M.M. Sychov, Procedia Engineering 189, 398-403 (2017) DOI:10.1016/j.proeng.2017.05.063

20. L.B. Svatovskaya, O.V. Urov, A.A. Kabanov, Procedia Engineering 189, 454-458 (2017) DOI:10.1016/j.proeng.2017.05.073

21. L.B. Svatovskaya, M.V. Shershneva, M.M. Baidarashvili, N.I. Yakimova, A.V. Khitrov, Proceedings of the International Conference on Sustainable Waste Management and Recycling: Construction Demolishing Waste (London, 2004)

22. L.B. Svatovskaya, A.S. Sakharova, M.M. Baidarashvili, A.V. Petriaev, Proceedings of the $14^{\text {th }}$ International Conference of International Association for Computer Methods and Recent Advances in Geomechanics (Kyoto, 2014)

23. A.M. Sychova, L.B. Svatovskaya, S.V. Mjakin, I.V. Vasiljeva, Electron Beam Modification of Solids: Mechanisms, Common Features and promising Applications, 35-37 (2009) 